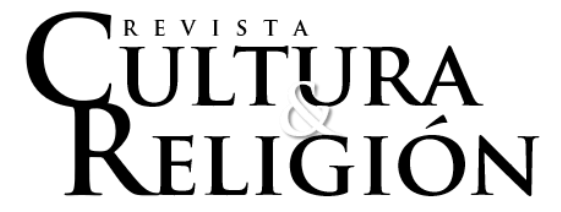

Vol. XIV, No 1 (2020) pp. 121-141

Recibido: 6 de marzo, 2020

Aceptado: 21 de mayo, 2020

\title{
MEANINGFUL STRATEGIES: TRANSCENDENCE IN CONDITIONS OF CONFLICT *
}

\author{
Estrategias con sentido: trascendencia en condiciones de conflicto
}

\author{
Heinrich W. Schäfer ${ }^{* *}$ \\ Bielefeld University, Germany \\ heinrich.schaefer@uni-bielefeld.de
}

\begin{abstract}
This article focuses on the concept of transcendence from a praxeological point of view. In consequence, in order to clarify the concept the author refers not only to theoretical debates but also to tangible empirical conditions. In the first part, based on the observation that religious practice makes strange claims about reality, he elaborates on epistemological aspects of religious communication and religious action. In the second part, by analyzing religious practice in the context of the Guatemalan Counterinsurgency War, he then discuss the usefulness and ambivalence of the concept of transcendence. Finally, on this basis, he designs a praxeological concept of transcendence.
\end{abstract}

Keywords: religion, transcendence, praxeology, Bourdieu, conflicts.

\section{Resumen}

Este artículo se centra en el concepto de trascendencia desde un punto de vista praxeológico. En consecuencia, para aclarar el concepto, su autor no solo se refiere a los debates teóricos, sino también a condiciones empíricas tangibles. En la primera parte, partiendo de la observación de que la práctica religiosa hace extrañas afirmaciones sobre la realidad, elabora algunos aspectos epistemológicos de la comunicación y la acción religiosa. En la segunda parte, analizando la práctica religiosa en el contexto de la guerra contrainsurgente guatemalteca, discute la utilidad y ambivalencia del concepto de trascendencia. Finalmente, sobre esta base, diseña un concepto praxeológico de trascendencia.

\footnotetext{
* The present article is an enlarged version of a contribution to the conference "Religion in Disputes, perspectives of legal anthropology", 27 to 29 October 2010, Max Planck Institute for Social Anthropology, Halle, Germany. The author draws heavily on Bourdieu and on diverse publications by the author himself; we simply mention Schafer (2015) on epistemology and Schafer (2020) on sociology of praxis. Moreover, almost all works in German have been removed.

** Dr. theol. habil., Ruhr Universität Bochum (Bochum, Germany). Dr. phil. rer. soc., Humboldt University (Berlin, Germany). Professor of Protestant Theology and Sociology, Bielefeld University (Bielefeld, Germany).
} 
Palabras clave: religión, trascendencia, praxeología, Bourdieu, conflictos.

\section{Introduction}

If somebody is insubordinate or claims his due, next morning he is dead. (...) Torture, kidnapping and so forth... (...) But true Christians do not tamper with this problem. As the verse of God's word says: Let me do it, (says the Lord) vengeance is mine! (Interview 6, field research of the author, 1985).

This is how a poor indigenous peasant, member of the Pentecostal Assemblies of God, during the counter insurgency war in Guatemala makes sense out of his cautious strategy. Another perspective on counter insurgency is given by an official of the upper class Neopentecostal $\mathrm{El}$ Verbo church to a group of journalists when asked about napalm bombing of indigenous villages: "The military does not kill Indians, it massacres demons since the Indians are possessed by demons, they are communists" (Carillo Ortiz, 1983, p. 56). ${ }^{1}$

Within a context of a violent conflict both sources resort to religious concepts. Both do it according to their social position, coming to very different conclusions. But both, however, resort to religion. They use transcendent, supernatural, otherworldly etc. beings to give a rationale for their practices; or -to be more precise- to create their praxis $^{2}$ out of the dense interaction between experience and interpretation, identity and action. Transcendence turns practical in a strongly theoretical sense of the term: In the flow of praxis the recourse to transcendence becomes an operator of practical logic (Bourdieu, 1977). There is no categorical difference between religious signs or symbols on the one hand and material things or social action on the other -so as if religion to religious actors were without a deeper significance, as if they simply used religious argument out of a cynical rationalist calculus; or, the other way around, as if they were simply determined by society or by their religion, a phenomenon sui generis which does not correspond to social conditions. Neither rationalistic and individualistic actor theories nor social or symbolic determinism will do to understand religious praxis -especially not with respect to the contexts of conflict, ranging from armed contention to legal disputes, in which religious actors in the recent past tend to emerge.

Legal anthropologists state that two concomitant processes are under way: juridification and enchantment, both undermining or replacing customary law and traditional forms of life. Religious praxis is involved in both enchantment and juridification, while acting on the former as on its proper field and increasingly taking over the latter. This could be seen as a hostile takeover by fundamentalists. ${ }^{3}$ However, there is a common ground for both processes: juridification normalizes custom. It establishes legal norms where custom is not plausible enough anymore. Of course, there might be different opinions about necessary

\footnotetext{
${ }^{1}$ The El Verbo church leader and private secretary to the dictator Efraín Rios Montt, Francisco Bianchi, is quoted in a US-House of Representatives' Hearing: "Clearly you had to kill Indians because they were collaborating with the subversives" (Committee on Banking Finance and Urban Affairs. House of Representatives, 1982, p. 57).

${ }^{2}$ We understand 'praxis' - quite similarly to Bourdieu - in the Aristotelian tradition as "bios" referring to all processes of human life in their mutual dependence; not as application in opposition to 'theory'.

${ }^{3}$ We understand "fundamentalism" as any kind of praxis that classifies its own premises as absolute and strives for imposing them on the public.
} 
norms. Fundamentalists might want to impose norms where ordinary people are happy with customs. But the important point is that common plausibility for juridification depends on a shared feeling that customary arrangements are not sufficient anymore to regulate a given situation. This is precisely the case in any kind of crisis that can range from role changes by modernization, migration, social exclusion to violent repression, civil war and terrorism. Thus, juridification is a means to regulate situations that are not regulated by the collectively habitualized cognitive and evaluative dispositions of the actors involved.

This is also the reason why juridification needs justification. And it is at this point that religious enchantment enters the game. It is very well known that religious praxis is a strong means to cope with situations of crisis. It adjusts cognition, emotion and action to these situations, thus framing them differently. It creates alternative fields and forms of action. It supplies institutional support and does even more still. Religious praxis is especially -and comparatively- strong in situations of crumbling social foundations; situations in which customary arrangements wither and secular juridification lacks legitimacy or, to put it figuratively, amidst the crumbling earth which lacks firm ground for laying deep foundations of new legal norms. Such a bedrock is supplied by religion. However -and this is the problem for secularist social scientists!- it is an invisible rock. But on the other hand, every believer knows that faith moves mountains (Mt. 21: 21). So, why shouldn't it move rocks to place where we need firm ground? And, moreover, social scientists know from Dorothy and William Thomas: "If men define situations as real, they are real in their consequences" (Thomas \& Thomas, 1928, p. 572).

In the present contribution I will discuss the issue of how social science can assess a specific religious praxis as such -and not as a perverted form of legal, neighborhood, political or whatever else kind of praxis. But I will not do it by simply resorting to religious argument such as members of the older phenomenological school (Otto, Heiler, Eliade, Van der Leeuw) might have done by referring to the numinous power of the sacred itself. Rather, I will proceed by analyzing the practical use of transcendence in a conflict situation. Before that, however, it seems appropriate to recall some epistemological remarks on understanding alien -that is, foreign and strange- praxis. Then, second, we will focus on the Central American case of conflict. Third, I will introduce the concept of transcendence for its usage in praxis theory. Finally, some reflections on practical transcendence will follow.

\section{Understanding strange practices: on the scientific assessment of religion}

\section{The Thomas theorem}

One thing to consider is the Thomas theorem with all its staggering evidence. The other, is religious practitioners sometimes doing really strange things which are quite hard to conceive of. And a third thing is that North Atlantic secularized intellectuals are quite unlikely to credit people with believing -and acting accordingly-that faith moves mountains. Of course, we take for granted that, for social scientists, it is irrelevant whether faith can move mountains or not. Social scientists, hopefully, are methodological agnostics precisely when it comes to the study of religiosity. However, the Thomas theorem remains valid however 'strange' or however normal religious behaviour might seem.

If this is true, researchers should accept that religious actors see the world differently than non-religious actors -and of course social scientists. Secondly, they should try to 
understand what religious people see when they see the world religiously. ${ }^{4}$ This is not to say that religious logics do not include strategies. Neither is it to say that these strategies cannot be linked to worldly effects or even goals. Nor is it to say that religious strategies are only focused on strictly religious praxis alone.

Finally, it is not to say either that a religious actor cannot have non-religious motivations. But it $i s$ to state that religious strategies are woven into religious identities that are constituted by faith in forces that are not of this world - forces that, for religious actors, of course can move mountains. Religious actors take for granted that they have a special relationship with beings or forces that are unobservable for social scientists. However, they might be willing to give interviews and to be observed by social scientists.

\section{Verstehen}

Then the scientific problem narrows down to the question of how to understand what we hear and see as religious praxis. For a sociologist, the term "understanding" connotes verstehen. In the well-known little passage on the woodchopper in Economy and Society (Weber, 1978), Max Weber reminds us that understanding a practice means understanding it "in terms of motive" as well. So, it is important to know why the woodchopper is chopping, e.g., to prepare firewood, for fun or to work off a fit of rage". The idea of a difference between external observation of a given practice and an internal dimension of such practice, in anthropology, finds a far more elaborated form in the emic/etic debate between Pike and Harris (Headland, Pike \& Harris, 1990) and the discussion of the natives' point of view in the context of symbolic anthropology (Geertz, 1976). While this is not the place to outline these debates, I would, however, like to state briefly what I think their consequences are for the study of religious praxis: first, in relation to meaning and then in relation to social structures.

\section{Meaning}

As related to meaning, it should be common ground that whatever "sense we have (...) of someone else's inner life, we gain through their expressions, not through some magical intrusion into their consciousness. It's all a matter of scratching surfaces" (Geertz, 1976, p. 73). This said, however, according to my view, research on religious praxis needs to understand and take the accounts of the practitioners seriously, as accounts from inside. It is necessary to understand to a certain extent what people think, how they perceive and judge, and why they act the way they do. In terms of religious praxis this means for a scientific observer to take it seriously that for religious actors their gods and demons are seriously real. But, of course, researchers do not believe in the reality and efficacy of these gods -maybe even their influence on their perception and writing. And if they do, they have to consciously put their faith aside in the attempt to be methodologically agnostic. It is this somewhat complicated status of belief in the research on religion that accentuates a general problem of the hermeneutics of 'the other'. An outsider's account of an insider's account can never be an insider's account, that is, can never be emic in a strict sense of the word. However, 'thick' a description might be, it is always a description filtered by the cognitive and emotional dispositions of the scientist. And these mostly implicit, subliminal schemes of perception and

\footnotetext{
${ }^{4}$ This means not to follow those who dissolve the specificity of religious praxis into universalistic truth claims about the liberal economy (Iannaccone, Finke \& Stark, 1997).
} 
judgment cannot simply be erased by such a practice as phenomenological epoché (Husserl, 2013) or rational reflection (Gadamer, 2001). Any researcher's understanding of insider's accounts is necessarily an outsider's account, is etic. The hermeneutical gap remains in place even if a native becomes a researcher, since this insider would have to work with categories apt to translate between two different objective fields of praxis: the 'native' culture/religion on the one hand, and the social science community on the other.

Researchers on religious practice also have to bridge this hermeneutical gap, and they should not do it at the expense of religious praxis itself, e.g. by classifying religious beliefs as in reality unimportant to believers, illusionary, irrational, instrumental etc. An attempt at bridge building, according to my view, needs a method that does not impose preconceived contents (as quantitative studies normally do), excludes implicit preconceptions of the researchers, elicits insider's accounts and, at the same, time offers a way of structuring them in sucha way that they are scientifically communicable.

\section{Social structures}

As related to social structures, in my view, it is important to recognize them as constitutive of meaning. Things and signs do not settle in separated ontological realms. The meaning of signs derives from their practical "use" (Wittgenstein, 1958). Signs are tools in life, and life develops within social structures. Moreover, structures (legal scriptures, judges, government, administration, military...) and things (streets, buildings, deserts, weapons, cars, bread...) are not just objects, dead cages for the creative subject to dwell in. Structures and things are signs, too. Just like words and rituals they are operators of praxis as well. Words, rituals, structures and things only make sense together. Thus, the position of a group within the world of things (e.g. its endowment with economic and political capital) influences its use of signs; and its position in the world of signs (e.g. its endowment with cultural capital) influences the use it makes of things and structures. Furthermore, the actors embody such complexly interwoven streams of practical relations between things and signs. Their specific worldview, its opportunities and constraints, their specific interpretation and evaluation of the social relations relevant to them, the regularities of life, the 'normal' successes and defeats etc. over time encode in their minds and bodies as the dispositions of their habitus. And these dispositions, for their part, operate in the practical logic the actors master their lives by. In consequence, for a social science account of (religious) meaning researchers should not only additionally consider "social structures", they should take them into account as constitutive operators of meaning construction.

\section{Praxeological research}

I think that much of the hermeneutical problem of how to understand strange practices can be solved by a praxeological research design. In the next chapter I shall exemplify such an approach with the study of two currents of Pentecostalism in the context of an armed conflict in Guatemala. At the center of the approach is the method of habitus analysis which I have developed and validated by a number of research projects over the last 25 years. This method triggers insiders' accounts on experience and its interpretation, and it structures the underlying practical logic according to very general formal categories - not according to any material contents (such as the concept of God, the idea of the family, the "understanding of the role of a judge etc.). Interviews are the basic sources of the accounts. Recorded sermons, (participant) observation, study of documents etc. can enrich the interpretation. The 
interviews are only slightly structured by questions in order to evoke utterances of four different kinds: negative and positive experiences, and the interpretation by which these experiences are explained. The basic idea is that everybody has negative and positive experiences and ascribes meaning to them. Secondly, the model operates on basic relations of logic: contrariness, contradiction, and implication.

These relations have been connected already during late Antiquity (Apuleius) in a model of logical transformations and used in the twentieth century for semiotic analysis by Greimas and Rastier. For its use in social science, I modified the logical model into a praxeological model by introducing the levels of experience and interpretation. In order to understand strange practices, it is important that the basic categories of the model (and, thus, the guiding interest in interviewing) are purely formal, very fundamental and simple, and therefore universal. There is nobody in this world who would not distinguish between good and bad, who would not ascribe some meaning to experience, who would not suppose that events have reasons to occur, or who would not have some idea of his own position in relation to others. So, the method simply helps to record people's accounts of their experience and their interpretations of these experiences - no matter what these experiences and interpretations are. The most open way to apply it is to ask what the most important problem is the person has to face, the most important hope the person nourishes etc. Of course, it is possible to adjust the method to different fields. Those interested in religion, in a later part of the interview, might want to not close with the question about the most important hope, asking in addition about the most important belief of a person. If the person is strongly religious, religious content most probably already will have surfaced with the question for the most important hope -if not, this can be taken as a hint that religiosity might not be too important for that person. Thus, while not focusing on content, the method leaves the interviewees free to 'fill in' the content relevant for them. It elicits insider's accounts and structures them according to a general scientific account of the nexus between experience and interpretation. Furthermore, the model can be used to structure a general theory of how identities and strategies are being constructed by practical operations. In sum, the outcome of this interpretative process is actor-specific models of the cognitive networks of dispositions (mental maps) that operate in the praxis of these actors. Such networks can be interpreted as networks of habitual dispositions, and they finally present the clue to understanding the identity and the strategies of a given social actor -be they religious or not. Such an actor can be individual or collective, since reconstructed individual networks can be aggregated according to similarity and differences, thus finding clusters of actors who operate similarly or differently. Individual cases can still be looked at individually, but they are also understood as part of a larger and structured quantity of actors -a collective case. Such an aggregation alone constitutes a specific field and indicates that the search for meaning is not about meaning as opposed to structure.

Structure is a requisite for meaning. It enters praxeological hermeneutics indirectly through the accounts of experience and directly through the theories and models of fields, social space, and the notion of capital that links structure and meaning with a specific reference to capability and power (Bourdieu 1995, 1983). ${ }^{5}$ Any of these models permits reconstructing the conditions under which meaning operates. Models of fields, according to

\footnotetext{
${ }^{5}$ On the religious field according to our concept, see Seibert (2018).
} 
Bourdieu, serve to reconstruct horizontal differentiation and, thus, to understand specific logics of praxis, such as economic as distinct from religious, as distinct from political etc.

Models of the social space of lifestyles (Bourdieu, 1984) serve to correlate cultural practices with social position in terms of economic and cultural capital. This model can, of course, be transformed for religious styles and constructed according to other forms of capital. For this article the only important thing is that the model of the social space allows positioning the actors studied within the broader social power structures in order to better understand the meaning of their religious practical logic. We will see that social position is an important factor when it comes to religiously coping with a seemingly identical social conflict and with apparently identical symbolic-religious resources.

\section{Religious praxis}

Religious praxis, according to a praxeological approach, can be understood as a specific kind of practical logic, but still as a practical logic comparable to e.g. political or economic logics. It operates by interpreting and generating experiences, it interacts with other practical dispositions of given human beings in order to shape their identities and strategies. Thus, religious practical logic blends into the cognitive, emotional and bodily processes that construct an actor's identity and strategy. Therefore, a religious identity is never something apart from an individual's or a group's wider identity. Religious practical logic builds upon operators of other logics such as political or juridical, it transforms them, it creates homologies between religious and other social practices and schemes of beliefs, it creates specific religious strategies, it boosts or dampens other strategies, it links up to the logics of other fields, translates problems and troubles of non-religious fields into religious language etc. And yet, religion is different. While any of the operations mentioned here are important for understanding religious praxis, the capability of religion to transform grievances into religious language and solve them symbolically might offer the best clue to the practical dimension of the distinctively religious operation in religious practical logic: the practical use of transcendence.

However, while this notion of religion makes sense in the framework of a praxeological approach, in social and religious sciences quite different concepts of religion are being used. ${ }^{6}$ Especially -and we will come back to this later- the difference between a merely functional concept of religion and a so-called substantial understanding is still relevant for research. Basically, this debate boils down to the question of how to conceive of 'transcendence'. This question is far from being merely technical or conceptual. For a rigorous analysis of any praxis - even the most descriptive ethnography-it is requisite to have a clear idea of the concepts used and not to compromise description with fuzzy terms. So, in order to grasp religious praxis, in my view, it might not be sufficient to simply state that religions refer to something otherworldly in general terms. In this sense, the well-known and to a large extent very useful definition of religion by Clifford Geertz could be more specific when it comes to the "general order of existence": Religion as "a system (...) formulating conceptions of a general order of existence (...)" is too broad a concept (Geertz, 1985, p. 4).

\footnotetext{
${ }^{6}$ On the interdisciplinary use of the concept of religion in political and religious sciences, see Hildebrandt \& Brocker (2008). On the ambivalence of religious mobilization in the context of violence, see Gopin (2000), Appleby (2001), Hasenclever \& Rittberger (2000).
} 
For a praxeological perspective on religious praxis, the specific religious content that the practitioners use to code transcendence by is important.

It is these contents the religious actors use to link up very specifically with the general conditions of life and/or the (problematic) situations they have to deal with. Different experiential contexts trigger different religious symbols even out of identical semiotic inventories, for example the Pentecostal one. Thus, the actors develop very different religious identities and strategies, including different concepts of the relation between the transcendent forces and society or history. This includes, of course, very different strategies in social conflicts and any kind of dispute. It is well known, for example, that the religious transformation of interest conflicts into identity conflicts often makes the contention more violent. Religious judgments, resorting somehow to absolute truths, give an ultimate colouring to penultimate disputes and conflicts. On the other hand, the reference to the absolute also might underscore the relativity of human beings and their interests.

In sum, we stress two levels on which the specifically religious reference to transcendence is important: First, between religious actors, employing different religious contents to code transcendence produces differences. These differences depend, as we will see, quite strongly on social position, interests, types of threats, and so forth. Second, between religious and non-religious actors, the mere reference to transcendence as such produces the basic difference. This difference depends -as we hypothesize- to a certain extent on the actor's ability to manage contingency, threats, suffering etc. by worldly means. The less an actor is capable of coping by ordinary techniques of everyday life, the more he will be inclined to extraordinary (Weber, 1978) measures. But the details of this difference are not the subject of this article.

In the following sections we can only go as far as to analyze the case of two currents of the Pentecostal movement in the context of the counterinsurgency war in Guatemala and then discuss some general features and problems of the recourse to transcendence as such. The case study of Guatemala combines two aims: to exemplify both a praxeological approach to religious praxis and ways of employing the recourse to transcendence in conditions of conflict and disputed basic rights.

\section{Transcendence and ambivalence in an environment of conflict: the Guatemalan case}

Below we will examine the case of Pentecostal churches during the armed conflict in Guatemala in the 1980s. We will see a double result, at first glance seemingly contradictory. First, religious identities and strategies are quite strongly influenced by social position. Second, the recourse to transcendent beings as something truly removed from the world's woes is constitutive for the religious praxis of these movements - especially in a situation of conflict and rapid social change. It is important to note from the beginning that the two currents present in our sample both develop their religious practical logics out of the same missionary Pentecostal, inventory of religious signs and symbols. In consequence, if different identities develop this is not due to completely different religious offers. It is due to different demands and, accordingly, to a different processing of religious semantics in identity and strategy construction.

In 1983 and during 1985 and 1986 I carried out, together with my wife, an anthropologist, a field study on religious movements in Guatemala and Nicaragua, 
comparatively. I conducted some 196 guided interviews in both countries, taped 112 sermons, did ritual analysis of services and, of course, kept a field diary.

The following considerations are based on the results of an intensive habitus analysis of two samples of 20 and 18 interviewees and 10 sermons, respectively, as well as on documentary analysis of grey literature.

\section{Habitus analysis}

As the whole research project was framed by Pierre Bourdieu's praxeological theory, it was necessary to fill the gap Bourdieu has left in terms of a method for qualitative research. So, I have developed the above-mentioned method of habitus analysis (Schäfer, 2015. 2020). The method is based upon Bourdieu's theories of habitus and practical logic. (Bourdieu, 1977, 1990). Actually, I read the theory of habitus from the angle of practical logic as well as from a Wittgensteinian and Pragmatist perspective. This is simply to underscore that the models used by habitus analysis should not be misunderstood in the orthodox structuralist way some handbooks wrongly depict Bourdieu's theory. It is not possible to go into much detail, here. However, the basic idea is the following. Social actors, individual or collective, perceive, judge and act according to a quite (but not thoroughly) coherent practical logic. The operations that take place in the related cognitive and affective processes involve positive and negative evaluation as well as interpretation of experience in a very general sense. This makes four terms: negative experience, interpretation (positive), positive experience, interpretation (negative). These terms can be related in a transformational model. Blueprints for this are some older models of logical (Aristotle, Apuleius) and semiotic (Greimas, Rastier) transformations. By adding the dimensions of experience and interpretation, a model for praxeological habitus analysis can be generated. Such a praxeological square enables an insight into the cognitive maps of individual and collective actors, (Schäfer, 2020) as well as into the processes of transformation from perception, through judgment to action (Schäfer, 2005). In other words, not only the specific utterances as forms of praxis have been focused and analyzed but also the way in which different utterances are operators of praxis (Schäfer, 2004). To understand these transformations, we had best begin on the lower right side of the square with negative experience (see annex). Applying the model to religious movements, the actors utter such negative experiences (1) as some kinds of grievances, uncertainties and threats. They counter these experiences with their specific promise of salvation; (2) their hope, their most important religious beliefs (interpretation positive in the model). From this promise they derive their self-description; (3) since the promise of salvation, the central belief, gives rise to special forms of religious praxis including rituals, distinctive practices, communities, institutions etc. This term models the self-description and self-positioning of the group in question (positive experience) over against the problems that it faces (negative experience). These three steps combine to the basic transformation that models the generation of identity of such group or movement. The second transformation models the generation of strategy. From its beliefs, practices and institutions (3, positive experience) a group or movement faces the articulated grievances and, most important, it ascribes reasons and causes to the grievances (4, interpretation negative), that is, it names the evil which can adopt very many faces.

Knowing the reasons for the grievances, the movement can design the strategies to fight them. Thus, the transformation from the practice of saving faith (3, positive experience), via naming some evil as reason for the grievances (4, interpretation negative) to countering 
the grievances (negative experience) models the strategy of the movement. ${ }^{7}$ Thus, the square combines identity and strategy formation very closely. ${ }^{8}$ However, this homology is produced by the model itself and needs more interpretation according to additional data from the interviews and the practical performance of the groups analyzed. With this in mind, it is useful, by further analysis of the interviews, to extend the model of the square to one of a whole network of operators (Schäfer, 2004, 2020). Nevertheless, this step would aim beyond the purpose of the present contribution which is to present findings of the research on Pentecostalism.

\section{Context and case}

As habitus analysis is not simply a qualitative research method focused on subjective states but is designed to be used in combination with models of the social space or of the relevant field (Bourdieu, 1984), we first make reference to the position of our Pentecostal samples in the Guatemalan social space. Guatemalan society is deeply divided into a rich, white upper class and a very poor, mostly indigenous lower class. This social division has deepened even more in political and military terms during the counterinsurgency war in the late 1970s and the 1980s. This war was one of the forerunners of a new, postmodern kind of war (Kaldor, 2012) involving, more that the modern kind of war, civilians within the infrastructure of war, as a source of money and supply, and as object for mobilization. In Guatemala -especially during the first phase of the open counterinsurgency war between 1978 and 1982-, the insurgent movement was strong and the extremely violent military repression was generalized in rural and urban areas, even in the capital. Since 1982 -the Rios Montt dictatorship - the violence of the military was systematically concentrated on rural areas. Napalm bombings, the concentration of indigenous civilians in strategic hamlets (similar to those of the US Operation Phoenix in Vietnam), torture, massacres with a strategically calculated effect of terror, the forming of civilian vigilante troops and many other measures of this kind affected the rural population deeply. In the capital, on the other hand, military and secret service violence was tempered so that the direct terror of the first phase was eased somewhat for the urban middle class. This is in no way to say that there was peace; but still there was some feeling of alleviation among urban middle class.

It is important for our research endeavor in religion and coping with conflict situations that the samples we look at are located in different social positions. The Neopentecostals -of different churches- belong to the modernizing urban upper middle class and even upper class: industrialists, higher and middle management, military officials, well established physicians and lawyers, and so forth. The Classical Pentecostals - mostly Assemblies of God-belong to the traditional (partly indigenous) lower class on the countryside and in urban slums: day laborers, small peasants, unschooled proletarians, street sellers, guards, cookshop workers, kiosk owners, and so forth. Because of historical reasons -that have to do with the insertion of the Neopentecostal movement into Guatemalan society but cannot be detailed here (Melander, 1999) - this division between Classical Pentecostalism and Neopentecostalism in Guatemala is much stronger than in most other countries of Latin America. But it is not an artefact produced by sampling. One could say that the special situation of the country - the

\footnotetext{
${ }^{7}$ Please be aware that the model reconstructs a logical transformation but does not depict a process in time with a beginning and an end.

${ }^{8}$ For field study, furthermore, it can be developed into an interview technique.
} 
peculiar insertion of Neopentecostals, politically connoted competition with Catholicism, the socio-economic gap, and the polarization due to the war - resulted in something like a laboratory condition for research on social differences.

\section{Conflict of interests}

Another important point to make is that the conflict as such is a typical conflict between material interests. It is not a conflict over religious identity or values (Goldstein \& Rayner, 1994) such as for example the conflicts in Bosnia-Herzegovina, Kashmir or Palestine have come to be. The matter of conflict is clearly the participation in economic resources and political power. The basic lines of conflict are quite clear, too: primarily between the upper and the lower strata of society; secondarily between traditional and modernizing factions. The modernizing upper position is represented by the stronger wing of the military, and the modernizing lower position by the guerrilla and social movements. The public debate about the situation in the country also orbits social, political and military issues. Religion has not served as a principal agent of mobilization as it does in identity conflicts. The conflict was not framed, for example, as one between Catholicism and Protestantism, or the like. Before Neopentecostal involvement, religious argument only interfered in conflict through theological and ethical judgment on economic disparity, violence etc.; on the one hand, through Liberation Theology, Catholic and Protestant base communities, and part of the Catholic clergy, on the other, as ethical judgment against social upheaval from the conservative part of the clergy. Thus, religious arguments served as a secondary source of legitimacy for certain political options, but not as devices for mobilization, previously identified with one of the conflicting parties. Furthermore, religious praxis, under conditions of war, plays an important role in people's coping with the practical and pressing contingency, often expressed in very concrete grievances related to personal life. In contrast to political mobilization, the anchoring of religious praxis in personal life is characteristic of religious praxis. It makes up its unique features for coping with especially difficult situations, it marks a certain distance from political mobilization and identification as such, and -at the same time, in a given situation- it is prone to even deepen and intensify public mobilization on political issues; and that is, turning them into issues of religious identity. In consequence, the special setting of the Guatemalan conflict allows observing three processes. How is it that religious praxis. We will have to focus on the first and the third issue, mentioning the second only marginally:

- Helps to cope with conflicts and related grievances, suffering etc.?

- Turns interest conflicts into identity conflicts?

- Has to rely on its relation to transcendence in order to perform its specific operations?

We will have to focus on the first and the third issue, mentioning the second only marginally.

\section{Classical Pentecostals}

The Classical Pentecostals in the lower class, especially in rural areas, are to an enormous extent victims of the war. One exceptionally open account: 
Here, in Guatemala, the military is in government (...) and they are very greedy, they crave for money (...) And therefore they keep the people under a very, very strong control". Question: Is it possible to solve the existing problems?

That's not possible anymore. If someone wants to solve them, the next day he has disappeared. (...) they kill him. (...) "You sleepy tightly, and all of a sudden they hit and kick the door, they come in and take you away and kill you. (Interview 9, the author, 1985)

It is not only insecurity but also pressing economic need, the impossibility to go to work on their acres, to feed the family and send children to school and, finally, the closure of any way to express the own interests by social or political mobilization. The corresponding grievances (praxeological square: position 1, negative experience) expressed a feeling of having lost any perspective of having a future in this life, summed up to an expression coined by many of my interviewees: “ $¡ N o$ hay para dónde! - There is no way out!”. How to answer such a demand and how to cope religiously with such a situation? The response of Classical Pentecostalism is apocalyptic. The actors counter such perception of their situation by hope in the return of Christ in the immediate future (position 2, interpretation positive). Christ is supposed to return in the present days and 'rapture' the true Church out of the world's suffering into heaven. In contrast to a situation without future, faith opens a perspective of heavenly future. It is this scheme from which the religious identity of these believers derives. They conceive of themselves as the true Church in preparation for the rapture (position 3 , positive experience). From this position, the explanation for their loss of future becomes evident: during the apocalypse everything necessarily changes for the worse.

Well, the Bible says that the return of Christ is near, when the signs are going to be fulfilled. (...) There will be earthquakes and wars and plagues and many other things. That is nothing to be surprised about. (Interview 9, the author, 1985)

The reason for the loss of all opportunities is interpreted as a logical consequence of living in the end times (position 4, interpretation [negative]) and therefore being the victims of a divinely necessary process from bad conditions into worse. Social action is rendered not only impossible but counter-productive. Accordingly, on the level of experience, we see a religious community that faces an extensive loss of opportunities for survival. In this situation, it opts for the following strategy: a clear break with political and social action and the withdrawal into the community of the church - exactly the strategy that, under repression and misery, allows survival and strengthens self-esteem through in-group solidarity. To sum up, people in a hopeless situation counter it with their hope in being taken up into heaven, and as Christians in preparation they refrain from any social or political mobilization and concentrate - de facto - on solidarity among their religious kin. It is a strategy of withdrawal from a hopeless situation into a manageable community of mutual support and solidarity.

\section{Neopentecostals}

The Neopentecostals in the modernizing upper middle class suffered the economic decline during the late 1970s and the insurgency of the early 1980s as processes that questioned deeply their initial ascent to a dominant political role in Guatemalan society. They 
cannot pay the debts resulting from a real estate purchase (Interview 67) or cannot afford a car they desire (Interview 22), they suffer personal setbacks like alcoholism and bulimia as consequence of stress (different interviews), they see corrupt politicians at work (Interview 86) or they feel "an existential void" (Interview 59/87) or just simply feel that there "must be something better for my life" (Interview 92). The habitus analysis shows that the grievances can be summed up as a sense of a generalized threat to middle class power, including the control over one's own body (position 1). Neopentecostal religiosity answers this demand charismatically, focusing on the power of the Holy Spirit (position 2) that followers can embody in the church by attending, praying, speaking in tongues and other ecstatic practices. This embodiment of power counters the experienced loss of control in life and it leads to a self-description as empowered individuals (position 3). It is not the church as a community but rather the individual embodiment of divine power that shapes this religious praxis.

(Baptism in the Holy Spirit is) (...) an experience of power by which the Holy Spirit takes the control over the whole person and empowers for the dimension of the Spirit, and that implies the gifts of the Spirit and all wonders. (Interview 101, by the author, 1986)

"Power is the piledup energy, the energy which the Holy Spirit accumulates within us to take it out again in case of need" (Interview 64, by the author, 1986). From the empowered position the believers ascribe the reason for the crisis in terms of power. It is the action of demons (position 4). Satan and his demons control social actors that compete somehow with (upper) middle class interests, such as unionists, guerrillas, indigenous people, some politicians and so forth: "Brothers, we face the reality of the ministers of Satan and their extraordinary and supernatural powers. (...) And we are the ministers of God!" (Sermon 97).

Furthermore, Satan afflicts any individual by taking control of its life. Thus, alcohol or drug misuse, bulimia and other problems are definitely caused by demons as well. Accordingly, the strategy is an active one: "Go to war with Satan, go to war with the demons, go to war with all difficulties, past and future! Seize power!" (Sermon 106, recorded, 1986).

Exorcism, the exclusion of the competing other, is the favorite strategy to solve, in all areas of life, the problems that the loss of control presents. This strategy can be experienced by one's own body, since believers can also be obsessed by demons and 'need' the help of ministers. This bodily experience with its religious interpretation, of course, serves as a cognitive and emotional anchor for the plausibility of exorcism as an overall social strategy for problem solving.

Thus, it is not very irritating that Neopentecostal believers in the Guatemalan mid1980s found it quite plausible to expel demons from "Indians". In contrast to the Classical Pentecostals of the same period the Neopentecostals' religious praxis revolves around power. It is not directed to a heavenly future. Rather it serves as a higher means to prosperity - as the so-called Prosperity the Gospel proclaims: "The will of God is that we live befitting our social status. And God is mighty enough to satisfy our needs". (Sermon 36, recorded by the author, 1986)

To sum up, upper middle-class citizens feel that an overall crisis in society challenges their control over their own economic, political and personal lives. They cope with this situation by clinging to the belief in and experiences of empowerment by the Holy Spirit in 
order to be able to fight the 'demons' that cause the loss of control with techniques of exorcism on the most diverse fields of social praxis. As this social class still has -in contrast to the lower-class people-real possibilities to act in society, the religious mobilization serves to concentrate power and to sharpen the strategy.

\section{Different identities}

After this overview of empirical findings we can distinguish a habitus of charismatic dominion over the world among the Neopentecostals of the upper middle class from a habitus of apocalyptic escape from the world among the Classical Pentecostals in the traditional lower class. Taking into account that both movements, during the 1980s relied heavily on a common inventory of religious signs and symbols, our finding corroborates that social position -translated into experience and interpretation- has an influence on religious habitus and praxis. This is precisely the reason why religious movements can enable their members to effectively cope with their specific social challenges.

As for the issue of identity politics we can conclude that the Neopentecostal strategy is inclined to employ religious identity for political goals insofar as the central strategy of exorcism tends to impose an intrinsically religious criterion (not an ethical one!) on social, political and military issues. However, while religious criteria are strong in the movement e.g. the preference for Christian politicians- they are not strong enough to be superimposed on a political calculus of interests. Classical Pentecostals, on the other hand, in terms of dealing with a conflictive situation and opponents, pursue a strategy of effectively avoiding conflict, reconstructing certain human security through communitarian solidarity, and maintaining self-esteem -at the expense of any intent of social, political or military action. One might want to call this passive identity politics.

Finally, it is crucial for both strategies that the religious actors resort to supra-human forces: God's making of history and the presence of the Holy Spirit. These forces are different, and this difference depends very much on the different opportunities for action that each movement has. Thus, the use of transcendence turns out to be quite practical. But still, for the believers it is most important that these forces are transcendent. This is what we focus our attention on in the following section.

\section{Gods and humans: on practical transcendence}

Gods might do well with transcendence by themselves. For humans it ought to be practical. Gods know the truth as such, and humans need to know a bit of it from time to time. Transcendence turns out to be practical, in its specific way, when humans resort to it for transforming the ambiguities of existence into clear-cut judgments and thus for managing contingency. In the following, we build on the hermeneutical reflections of the first part especially the somewhat Wittgensteinian relation between signs and things- and will refer occasionally to the Guatemalan case. First, we will examine briefly the concept of transcendence as such. Then we will look at different definitions of religion with regard to their concept of transcendence. We will close with a brief glimpse at practical transcendence in situations of conflict.

\section{Transcendence}


The concept of transcendence, today, is a scientific term used in social science and humanities. Thus, it is quite similar to the term religion which serves to scientifically construct a certain field (or system) of human praxis as distinct from others. Moreover, both concepts are mutually dependent insofar as the definition of one of them determines the definition of the other, and vice versa. If the definition of transcendence is purely negative and formal -as it is the case in functional definitions (see below)- many social practices can take on a religious character. If the definition of transcendence postulates otherworldly beings or forces -as in substantial phenomenological definitions- religious practices are limited to the devotion of such forces.

As for the definition of religion, today the universalistic hope for an overarching and true definition has given way to pragmatic solutions (Platvoet \& Molendijk, 1999). That means definitions are operators in scientific strategies aiming at the explanation of a given kind of praxis. While such pragmatics are a good antidote against meaningless ontological dispute in social sciences, it is still necessary to have some operational definition of religion as one goes into the field. One simply should be able to say what distinguishes religious praxis from other kinds of praxis. My own answer to this question is very much in line with the pragmatic solution, referring back to a Wittgensteinian approach. In general, religious praxis operates as any other praxis related to meaning: by interpretation. It structures and evaluates perception by specific symbolic means, ${ }^{9}$ generating and regenerating experience. In analogy to Wittgenstein's term of seeing as (Wittgenstein 1958, part II, chapter XI.), according to John Hick religious praxis is a special form of experiencing as (Hick, 2005). That implies two important consequences. First, religious praxis makes up part of the overall stream of human experience. On the level of personal praxis it is -or, at least, can beintimately linked to any kind of experience, be it in partnership, health, law, education, tourism, fashion, neighborhood, politics, violence or whatever. At the level of institutions, religious praxis might be more strongly forming a realm with distinct institutional logics, but still religious institutions are distinct from other (non-religious) institutions by a different way of relating to general social praxis. It is precisely here where transcendence comes in.

Religious praxis is distinct from other forms of human praxis by its interpretative reference to transcendence. But, what is transcendence?

For social science, transcendence as such is nothing. As an operator of religious praxis, on the other hand, transcendence opens an immense field for social research. The concept transcendence however needs some clarification. First, just as the term religion I use it as a pragmatic operator for research. Second, as an operator in research it is especially useful if it remains formal without any reference to religious content -in order to give room to the religious content the actors themselves fill into the void left by the scientific tool. Accordingly, a crucial point for clarification is the debate between content and functionoriented concepts of religion and transcendence. Before we go into that, third, I would like to delimit our use of the concept of transcendence somewhat more.

Many scholars of religion - especially with Weberian and Durkheimian backgroundsee the distinctiveness of religious practice in its dealing with a backworld (Weber, 1978) or otherworldly, Weber or superhuman powers (Riesebrodt, 2010), while in a Tylorian perspective dealing with death is understood as distinctive of religion. There is something

${ }^{9}$ If Geertz's symbolic system'(Geertz, 1985) is understood as a means to interpret social structures and practices, our approach is near to Geertz as well. 
common between all these approaches. It is the line drawn between two realms, one of which is open to ordinary human action and understanding and the other is not. In consequence the question is whether the concept of transcendence is useful to scientifically operationalize this line between the realms.

Etymologically, transcendence means to step across a boundary. With this processual meaning the word has been used e.g. by Augustine to give form to the theological outside an etic account of the opening of the believer's heart onto God. Such a processual understanding still is common in Catholic thinking. Another process description with reference to transcendence is the theory of the axial age (Jaspers, 1953; Eisenstadt, 1986). Here, the term transcendence designates a stage of objective religious evolution. Transcendent (all?) religions are characterized by the consciousness of something divine that overarches human societies, contrasts the worldly human business, and normally is communicated by divine revelation. In other words, the term transcendence in this meaning refers to a very special kind of line between the human and the non-human. Furthermore, it is identified with a special period in time. And its use in religious studies would exclude much of past and even present religious praxis.

Historically there is another, non-processual, use of the term. Since William of Occam the term is used to designate a strict line of boundary that separates, ontologically and gnoseologically, the human from the divine sphere. I plead for such a formal use of the term in religious studies. However, while in Occam the postulate of the boundary is a theological -that means an emic- account, religious studies apply the model of such a line merely in a formal and heuristic way. The term is a tool to formally designate a distinction between ordinary and extraordinary, human and beyond-human actors and practices. The application of this tool is purely heuristic. It is the religious actors that provide the content to describe the line of boundary, the beings beyond the line, and the activities to cross it. For example, to incorporate a divine spirit by trance is surely another concept of crossing the line than to wait for Christ to come back in the clouds; to study the Bible or the Qur'an in search of revelation is surely another way than to tend prayer flags between huts in the Himalaya or to fly in a shamanistic ride to the 'realm of the sun' to be charged with energy for healing.

But any of these practices presuppose that line between the humans and something different, higher, and bestowed with special powers. Understood like this, any human praxis that fulfils the following criterion can be treated as religious praxis by social research: Religious praxis establishes a categorical difference between ordinary human practices and interpretations, on the one hand, and extraordinary practices and interpretations which make reference to forces beyond human control but relevant to human life, on the other hand. In consequence, it is neither necessary nor helpful to establish categorical differences between various forms of religious praxis. Instead -and differently from axial age theorists- one can think of a large continuum between religious practices very closely knit into the experience of the surrounding nature versus others based on the belief in a very distant and imageless God. On the one end of this continuum thus might be located the realms of shamanistic voyages to non-human realms or the blissful land of the Bulotu-Island in Tonga religion (Culianu, 1991); on the other end might be found the prohibition of any image for JHWH, the universal and eternal, or the neo-Platonian Negative Theology as e.g. in Meister Eckhart. While the line of transcendence characterizes all of them, each one has its own ways to imagine this distinction and deal with it. 
In consequence the experiential and interpretative religious content, as communicated by the practitioners, is crucial to understand religious praxis even if the tool to identify it remains formal. ${ }^{10}$ But how can formal and content dependent operations merge into a theory of religion that serves for understanding religious praxis in its social context.

\section{Transcendence - substantial, functional and praxeological}

The distinction between formal and content-oriented operations recalls an ongoing discussion in religious studies (that to some extent parallels the difference between functionalist and symbolic anthropology): substantial versus functional concepts of religion each of which implies a specific understanding of transcendence. (Riesebrodt 2010; Pollack, 1995). The substantial concept has been fostered very much by phenomenologists of religion such as Rudolf Otto and Mircea Eliade. The Holy, the transcendent, is not only conceived as imagined religious content but as making itself present by its appearance, thus granting a quasi-religious character even to religious studies. Functional definitions -such as by Milton Yinger, Thomas Luckmann or Niklas Luhmann- focus on the religions' capacity to deal with contingency. While this cannot, by far, be justly reported here, for us it is important that the approaches need not be categorically divided and that each of them offers useful insights. If the phenomenological approach is being reinterpreted in a non-metaphysical way, it helps to understand the reference of religious actors as being shaped by specific content; and moreover the amount of phenomenologist's knowledge of detail helps the social scientist to keep in touch with real religious praxis and not to vanish into merely theoretical spheres.

The functionalist theory is important for its reminder that religion deals with contingency. But the concept of contingency is not sufficiently grounded for praxeological research when only understood as the fact that things could be different from what they are (Luhmann, 1984). For the research of religious praxis, it should be interpreted in terms of crisis, changes, breakdowns, etc. according to the experience of the actors studied. Finally (experienced), contingency and (interpretative) transcendence in religious praxis do not operate distant from each other, but only in an intimate relation. A praxeological approach to religious study treats both, transcendence and contingency, in relation to each other. This is not only the case in theory but also in methodology. The praxeological square realizes this approach in terms of an analytical model of the transformations between social experience and its religious interpretation.

Focusing on the relation between transcendence and contingency, let us first describe transcendence. Transcendence is always concrete in terms of religious ideas that connote content to it: saints, demons, angels, gods, tricksters, invisible causalities such as dharma in Buddhism, eternal laws etc. Religious actors conceive of it as an actual, tangible, sturdy reality as opposed to real, actual and sturdy experiences of crises, change, chaos, death and so forth. Only if transcendent beings and forces are imagined as real and powerful by religious actors and if they are not all too similar to earthly creatures, there can develop such an energetic praxis as many religions have. The other term of the relation, contingency, is

\footnotetext{
10 The formal operation with the term of transcendence reminds of Niklas Luhmann. The basic distinction that constitutes religion as a 'system' is the distinction of 'transcendence versus immanence'. The specificity of religion is to 'cipher' transcendence with concrete content and, thus, to veil the distinction itself. This content as such, however, for Systems Theory is not important for the understanding of religion. For actor-oriented theories, however, the religious content and the contextual conditions of its use are crucial (Luhmann, 2000).
} 
being experienced by religious actors very concretely as crises, death, up-rootedness etc. And such experiences are interpreted resorting to more or less corresponding inventories of religious symbols that refer, somehow, to transcendent powers. If religious praxis is to produce practical meaning and thus is to make sense to the actors, the experience of concrete misery and evil has to be answered by a specific promise of salvation - not by any one. And the experience of social calamities cannot be interpreted and answered religiously if not by religious signs/symbols actively known by the persons concerned. The experience of the counterinsurgency war in Guatemala did not generate just one single Pentecostal religious answer (as merely semiological theories of religion might want to suppose). It generated very different Pentecostal forms of praxis according to different ways of experiencing the contingencies of war; and the different religious contents connoted to transcendence resulted in very different religious strategies among each, the Classical Pentecostals and the Neopentecostals. This result is not accidental. It corresponds to the distinction that Max Weber makes between a theodicy of good fortune and a theodicy of suffering. Thus, social experience and religious interpretation, contingency and transcendence, grievances and promise of salvation, work together and are mutually dependent when it comes to generating religious practical logic. Transcendence becomes practical.

\section{Practical transcendence - a conclusion}

To conclude this article, I will share some very brief lines on the practical use of transcendence in situations of conflict and disputes. Normally, a secular researcher tends to think that religious actors in situations of non-religious dispute or of conflicting interests would want to adapt their reasoning to non-religious standards in order to communicate better.

While this normally is the case with well-established, relatively powerful and somewhat rationalistic religious institutions in the North Atlantic, it is often the other way around with somewhat marginal movement actors in the North Atlantic (Tea Party, Religious Right) and with almost any religious movement all over the world. A glimpse at the practical use of transcendence and its conditions might shed some light on the issue.

Religious praxis is pinned on the belief that there is someone or something beyond this world able to give conclusive answers and solutions to both the most existential and far reaching mysteries of existence (creation, eternity, death) as well as to the most urgent and intimate needs of daily life (our daily bread...). The situation in the world and its perception represented by the level of experience in our model, is characterized by ambiguity. Religious interpretation makes things unequivocally plain. At the same time, the conditions of life although ambiguous regarding their evaluation- are experienced as hard facts that determine to a large extent the possibilities of action; but the recourse to transcendence in religious interpretation of experience is relatively free in terms of the content connoted to it. Thus, the corresponding symbolic content, connoted to transcendence in different religious currents, establishes a space of interpretative possibilities. Out of such a bundle of signifiers -the Holy Spirit, the Crucifiction, God the Father, the Resurrection, the Virgin Mary, power, suffering, love, rapture, prophecy etc., to mention only a Christian inventory- religious actors can choose those that best fit their needs of meaning under the given social conditions and in accordance to their specific grievances. Once chosen and used for interpretation the respective content acquires its specific meaning for the specific religious praxis of these 
actors and establishes clear-cut material criteria for interpreting and evaluating the social and religious conditions: lower class Pentecostals take it as an end-time situation that longs for Christ to come back; upper class Neopentecostals take it as a situation of deadly competition that longs for their own empowerment and strategies of exclusion.

In order to render the religious re-interpretation of the world effective it is not only necessary that the religious content fits the needs. It is also recommendable that the content in its character as transcendent is sufficiently different from worldly affairs. Transcendent powers can only work effectively if they are really transcendent, that is at least supernaturally strong and, hopefully, not all too corrupted by worldly interests when it comes to arrange something in the world of the mortals. One of the reasons that Liberation Theology lost appeal to people in Latin America seems to be the fact that its promise of salvation has become too similar to secular hopes for revolutionary change. Religious interpretation derives its power from the claim of reflecting a strong and ultimate transcendent power, especially when societies are strongly differentiated in terms of function. It is the otherness of the transcendental being or force in relation to the world (not its similitude to it) that establishes certainty in the followers. The otherness guarantees a relevant qualitative difference between religious praxis and any other social form of praxis. It reassures mortals of its great superiority when it comes to solving the problems of life and entering into conflicts and disputes. It is precisely the proclaimed distance of the religious sources of legitimacy from the realm of worldly affairs that renders special plausibility to religion in situations of crisis. And it fuels religious praxis with special dynamics, both for exacerbated radicalism and devoted peacefulness. Distance and difference of religious reasoning from the logics of the world can facilitate - e.g. in radical conversions- a complete restructurating of perception, judgement and action, thus opening people up to finding completely new solutions to old problems - peaceful or violent ones, retreat and reorganization of communities or holy war. It is this dynamic that operates behind religious radicalism. Fundamentalist strategies of domination can easily disregard the human survival instinct and opt even for strategies of self-damaging violence. Religious commitment to peaceful conflict resolution and for the protection of the persecuted can turn into martyrdom -both with recourse to practical transcendence.

\section{References}

Appleby, R. S. (2001). Religion as an Agent of Conflict Transformation and Peacebuilding. In C. A. Crocker, F. O. Hampson and P. Aall (eds.), Turbulent Peace. The Challenges of Managing International Conflict (pp. 821-840). Washington: United States Institute of Peace Press.

Bourdieu, P. (1977). Outline of a Theory of Practice. Cambridge: Cambridge University Press.

Bourdieu, P. (1983). The Field of Cultural Production or the Economic World Reversed. Poetics, 12(4-5), 311-356.

Bourdieu, P. (1984). Distinction. Cambridge, MA: Harvard University Press.

Bourdieu, P. (1990). The Logic of Practice. Cambridge: Polity Press.

Bourdieu, P. (1995). The Rules of Art. Stanford, CA: Stanford University Press. 
Carillo Ortiz, M. (1983). La iglesia evangélica en Guatemala. Testimonio del Rev. Mario Carillo Ortiz, Pastor evangélico de Guatemala. Polémica, № 9, 54-56.

Committee on Banking, Finance and Urban Affairs. House of Representatives (1982). InterAmerican Development Bank Loan to Guatemala. Hearing before the Subcommittee on International Development Institutions and finance. Series 97-80. Washington D.C.: House of Representatives.

Couliano, I. P. (1991). Out of this World. Boston. London: Shambhala.

Eisenstadt, S. N. (ed.) (1986). The Origins and Diversity of Axial Age Civilizations. Albany: State University of New York Press.

Geertz, C. (1976). From the Native's Point of View. In K. H. Basso and H. A. Selby (eds.), Meaning in Anthropology (pp. 221-237). Albuquerque: University of New Mexico Press.

Geertz, C. (1985). Religion as a Cultural System. In M. Banton (ed.), Anthropological Approaches to the Study of Religion (pp. 1-46). London: Tavistock.

Geertz, C. (1986). Making Experiences, Authoring Selves. In V. Turner and E. Bruner (eds.), The Anthropology of Experience (pp. 373-380). Urbana: University of Illinois Press.

Goldstein, J. \& Rayner, J. (1994). The politics of identity in late modern society. Theory and Society, 23, 367-384.

Gopin, M. (2000). Between Eden and Armageddon. Oxford: Oxford University Press.

Hasenclever, A. \& Rittberger, V. (2000). Religionen in Konflikten. Jahrbuch Politisches Denken (pp. 35-60). Berlin: Duncker \& Humblot.

Headland, T., K. Pike \& Harris, M. (eds.) (1990). Emics and Etics. The Insider/Outsider Debate. Newbury Park, CA: Sage Publications.

Hick, J. (2005). An Interpretation of Religion. New Haven CT: Yale University Press.

Hildebrandt, M. \& Brocker, M. (eds.) (2008). Der Begriff der Religion. Wiesbaden: VS Verlag für Sozialwissenschaften.

Iannaccone, L., Finke, R. \& Stark, R. (1997). Deregulating Religion. Economic Inquiry, 35(2), 350-364.

Jaspers, K. (1953). The Origin and Goal of History. New Haven: Yale University Press.

Kaldor, M. (2012). New and Old Wars. Cambridge: Polity Press.

Luhmann, N. (1984). Die Wissenschaft der Gesellschaft. Frankfurt am Main: Suhrkamp.

Luhmann, N. (2000). Die Religion der Gesellschaft. Frankfurt am Main: Suhrkamp.

Melander, V. (1999). The Hour of God. Uppsala: Studia missionalia Upsaliensia.

Platvoet, J. G. \& Molendijk, A. (1999). The Pragmatics of Defining Religion. Leiden: Brill.

Pollack, D. (1995). Was ist Religion? Zeitschrift für Religionswissenschaft, 2, 163-190.

Riesebrodt, M. (2010). The Promise of Salvation. Chicago: University of Chicago Press.

Schäfer, H. W. (2015). HabitusAnalysis 1. Epistemology and Language. Wiesbaden: Springer.

Schäfer, H. W. (2020). HabitusAnalysis 2. Praxeology and Meaning. Wiesbaden: Springer.

Seibert, L.-H. (2018). Religious Credibility under Fire. Wiesbaden: Springer.

Thomas, W. I. \& Thomas, D. S. (1928). The Child in America. New York: Knopf.

Weber, M. (1978). Economy and Society. Berkeley: University of California Press.

Wittgenstein, L. (1958). Philosophical Investigations. Englewood Cliffs: Prentice Hall. 


\section{Annex: The praxeological square: religiosity and religious movements}

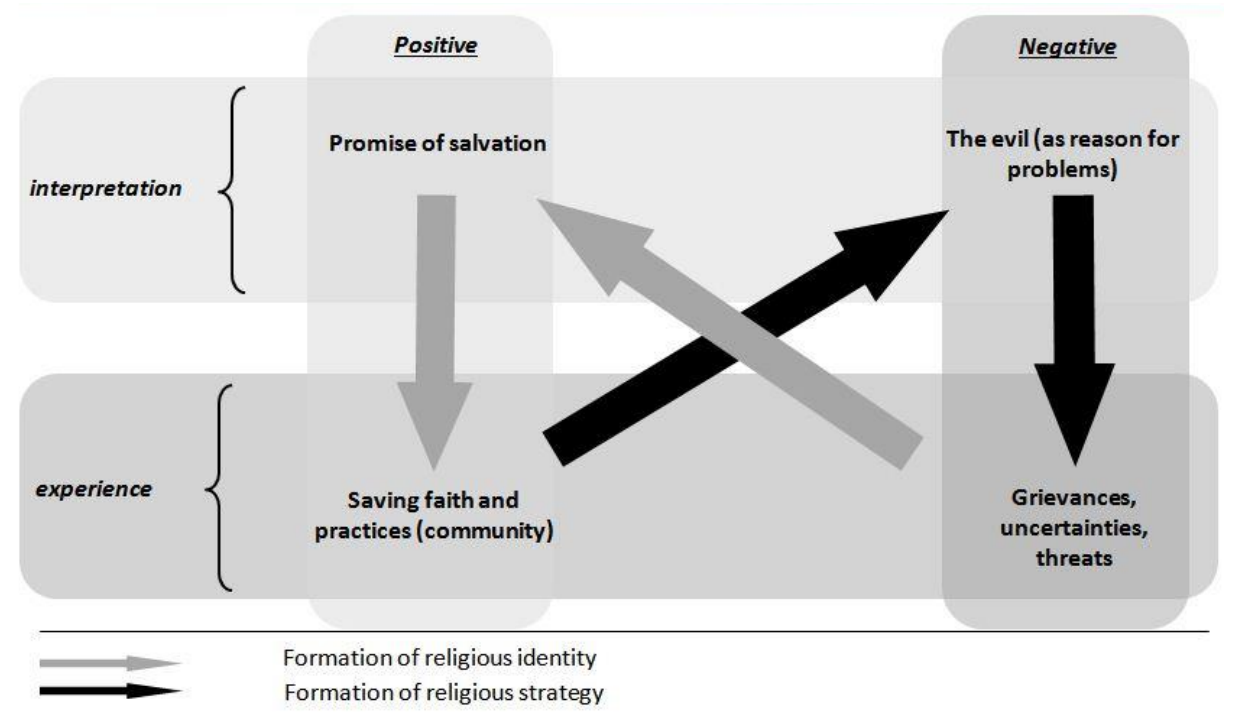

Font: Author's elaboration.

\section{Cómo citar este artículo}

Schäfer, H.W. (2020). Meaningful strategies: transcendence in conditions of conflict. Revista Cultura \& Religión, 14(1), 121-141. 